\title{
Nitrogen addition reduced carbon mineralization of aggregates in forest soils but enhanced in paddy soils in South China
}

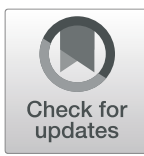

Ruirui $\mathrm{Cao}^{1 \dagger}$, Longchi Chen ${ }^{2,3^{*+}} \mathbb{D}$, Xincun Hou ${ }^{4}$, Xiaotao Lü ${ }^{2}$ and Haimei $\mathrm{Li}^{1^{*}}$

\begin{abstract}
Background: Despite the crucial role of nitrogen (N) availability in carbon (C) cycling in terrestrial ecosystems, soil organic C (SOC) mineralization in different sizes of soil aggregates under various land use types and their responses to $\mathrm{N}$ addition is not well understood. To investigate the responses of soil $\mathrm{C}$ mineralization in different sized aggregates and land use types to $\mathrm{N}$ addition, an incubation experiment was conducted with three aggregate-size classes (2000, 250, and $53 \mu \mathrm{m}$ ) and two land use types (a Chinese fir plantation and a paddy land).

Results: Cumulative $C$ mineralization of the $<53-\mu \mathrm{m}$ fractions was the highest and that of microaggregates was the lowest in both forest and paddy soils, indicating that soil aggregates enhanced soil $\mathrm{C}$ stability and reduced the loss of soil $\mathrm{C}$. Cumulative $\mathrm{C}$ mineralization in all sizes of aggregates treated with $\mathrm{N}$ addition decreased in forest soils, but that in microaggregates and the $<53-\mu \mathrm{m}$ fraction increased in paddy soils treated with $100 \mu \mathrm{g} \mathrm{N} \mathrm{g}{ }^{-1}$. Moreover, the effect sizes of $\mathrm{N}$ addition on $\mathrm{C}$ mineralization of forest soils were below zero, but those of paddy soils were above zero. These data indicated that $\mathrm{N}$ addition decreased $\mathrm{SOC}$ mineralization of forest soils but increased that of paddy soils.

Conclusions: Soil aggregates play an important role in soil $\mathrm{C}$ sequestration, and decrease soil $\mathrm{C}$ loss through the increase of soil $\mathrm{C}$ stability, regardless of land use types. $\mathrm{N}$ addition has different effects on soil $\mathrm{C}$ mineralization in different land use types. These results highlight the importance of soil aggregates and land use types in the effects of $\mathrm{N}$ deposition on the global terrestrial ecosystem C cycle.
\end{abstract}

Keywords: Ultisol, Land use type, Microaggregates, Soil organic carbon

\section{Introduction}

Soils are the largest sink of the global carbon (C) cycle and hold $2500 \mathrm{Gt} C$ that are 3.3 times the size of the atmospheric $C$ pool and 4.5 times the size of the biotic $C$ pool (Lal 2004). The maintenance of the soil C pool is critical to the global $\mathrm{C}$ cycle and climate change as even slight changes in the soil organic $\mathrm{C}$ (SOC) pool can

\footnotetext{
* Correspondence: Icchen@iae.ac.cn; lihaimei75@163.com

${ }^{\dagger}$ Ruirui Cao and Longchi Chen contributed equally to this work.

${ }^{2}$ Huitong Experimental Station of Forest Ecology, CAS Key Laboratory of

Forest Ecology and Management, Institute of Applied Ecology, Chinese

Academy of Sciences, Shenyang 110016, China

${ }^{1}$ College of Landscape Architecture and Forestry, Qingdao Agricultural

University, Qingdao 266109, China

Full list of author information is available at the end of the article
}

seriously affect atmospheric $\mathrm{CO}_{2}$ concentration and global $\mathrm{C}$ budget (Schlesinger and Andrews 2000; Bellamy et al. 2005). Hence, the loss of SOC has received increasing attention in recent years (Liu et al. 2017; Qiu et al. 2018; Yanni et al. 2018; Wiesmeier et al. 2019). Approximately half of all SOC in managed ecosystems has been released to the atmosphere during the last two centuries, of which two-thirds is attributed to SOC mineralization (Lal 2004; Kirkby et al. 2013). Therefore, the study of the influencing factors and mechanisms of SOC mineralization could improve the understanding of the soil $\mathrm{C}$ cycle and their role in global climate change.

Except for soil temperature and moisture, which are the main factors controlling SOC mineralization

\section{Springer Open}

๑ The Author(s). 2021 Open Access This article is licensed under a Creative Commons Attribution 4.0 International License, which permits use, sharing, adaptation, distribution and reproduction in any medium or format, as long as you give appropriate credit to the original author(s) and the source, provide a link to the Creative Commons licence, and indicate if changes were made. The images or other third party material in this article are included in the article's Creative Commons licence, unless indicated otherwise in a credit line to the material. If material is not included in the article's Creative Commons licence and your intended use is not permitted by statutory regulation or exceeds the permitted use, you will need to obtain permission directly from the copyright holder. To view a copy of this licence, visit http://creativecommons.org/licenses/by/4.0/. 
(Contosta et al. 2013; Wang et al. 2016), soil nutrient availability, especially nitrogen $(\mathrm{N})$ availability, greatly influences SOC mineralization through their impact on the decomposition and formation of soil organic matter (Reed et al. 2010; Poeplau et al. 2016; Soong et al. 2018; $\mathrm{Zhu}$ et al. 2018b). Moreover, $\mathrm{N}$ inputs from anthropogenic sources to biosphere, such as agricultural activities and fossil fuel combustion, are tenfold higher now than 100 years ago (Galloway et al. 2008), resulting in the continuous increase of soil $\mathrm{N}$ availability (Aber et al. 1998). Thus, the role of soil $\mathrm{N}$ availability in SOC mineralization is further highlighted. $\mathrm{N}$ addition is an important approach to change soil $\mathrm{N}$ availability, such as fertilization and $\mathrm{N}$ deposition. Although $\mathrm{N}$ addition is widely believed to reduce the rate of SOC mineralization (Mo et al. 2008; Fisk et al. 2015; Riggs et al. 2015; Guo et al. 2017; Hu et al. 2017; Zhu et al. 2018a), a few studies reported that $\mathrm{N}$ addition has no effects (Micks et al. 2004; Allison et al. 2008), even positive effects on SOC mineralization (Cleveland and Townsend 2006; Huang et al. 2011a; Zhao et al. 2019). This controversy may be because the level of $\mathrm{N}$ addition results in different responses of SOC mineralization (Allison et al. 2009; Zhu et al. 2016). However, why are there variable responses of SOC mineralization to $\mathrm{N}$ enrichment and what is the mechanism controlling these responses to $\mathrm{N}$ enrichment remain unknown.

The rate of SOC mineralization is controlled by SOC stability (Tian et al. 2016), and the protection of soil aggregates is proposed as one of the main mechanisms of SOC stabilization (Six et al. 1998; von Lützow et al. 2008; Chaplot and Cooper 2015). Soil aggregates, especially macroaggregates, can protect the SOC against microbial decomposition (Six and Paustian 2014) due to spatial inaccessibility to soil microorganism (Goebel et al. 2005; von Lützow et al. 2008). Different particle sizes of soil aggregates have distinct characteristics in the soil C turnover (Besnard et al. 1996). Many studies suggested that the rate of SOC mineralization was lower in macroaggregates than in microaggregates (Drury et al. 2004; Xie et al. 2017). However, no difference of SOC mineralization between macroaggreates and microaggregates (Razafimbelo et al. 2008) and even the opposite results (Wang et al. 2015; Bimüller et al. 2016; Yang et al. 2017) have been reported. Although no consistent conclusion exists about the SOC mineralization of different sizes of soil aggregates, SOC mineralization is widely believed to vary (Razafimbelo et al. 2008; Bimüller et al. 2016). The distinct compositions of soil aggregates with varying particle sizes in soils may result in the differences of SOC mineralization. Moreover, the responses of $\mathrm{C}$ mineralization of soil aggregates to $\mathrm{N}$ addition remain unclear, limiting the understanding of the influencing factors of SOC mineralization with $\mathrm{N}$ addition treatment. The differences in SOC stability of varying sizes of aggregates may cause the distinct responses of $\mathrm{C}$ mineralization of soil aggregates to $\mathrm{N}$ enrichment, resulting in the differences of $\mathrm{C}$ mineralization of bulk soil with $\mathrm{N}$ addition treatment. However, direct evidence of the effects of $\mathrm{N}$ addition on SOC mineralization of varying size aggregates is lacking (Riggs et al. 2015; Xie et al. 2017). Investigating the responses of C mineralization of soil aggregates to $\mathrm{N}$ addition can further explain the mechanism that controls the influence of $\mathrm{N}$ enrichment on SOC mineralization.

In addition, land use type can influence the soil aggregate distribution and aggregate stability index (Zhong et al. 2019; Okolo et al. 2020). For example, soil microaggregates were dominant under cultivated land, while soil macroaggregates were preponderant in grazing land (Okolo et al. 2020). Zhong et al. (2019) also suggested that the conversion from farmland to forest increased the proportions of soil macroaggregates and mesoaggregates and thus increased the organic carbon accumulation. The changes of soil aggregate distribution after land use change may alter the soil $\mathrm{C}$ mineralization. Moreover, different land use types have different management intensities, for example, more fertilization and tillage in farmland. Management intensity can affect the soil aggregate distribution (Sithole et al. 2019; GonzálezRosado et al. 2020) and then result in the change of soil C mineralization (Reeves et al. 2019). As forest and paddy are the main land use types in south China, the effects of $\mathrm{N}$ addition on their soil $\mathrm{C}$ mineralization are crucial to understanding the global $\mathrm{C}$ cycle. However, little is known on the difference of effects of fertilization on soil $\mathrm{C}$ mineralization among land use types.

In this study, we examined $\mathrm{C}$ mineralization over 3 months in macroaggregates, microaggregates, and the < $53-\mu \mathrm{m}$ fraction in forest and paddy soils after the application of $\mathrm{N}$ fertilizer with a concentration gradient using a laboratory incubation experiment, to uncover the impacts of $\mathrm{N}$ addition on soil $\mathrm{C}$ mineralization in different aggregate sizes under different land use types. The specific objectives of our study are to (1) examine whether the SOC mineralization and their responses to $\mathrm{N}$ addition differ among aggregate sizes and (2) determine whether the effects of $\mathrm{N}$ addition on SOC mineralization are the same between different land use types (forest and paddy). We hypothesized that (i) the rates of $C$ mineralization increase with decreasing size class of soil aggregates and (ii) the responses of $\mathrm{C}$ mineralization in forest and paddy soils to $\mathrm{N}$ addition are different.

\section{Materials and methods}

\section{Study area}

This study was conducted in the Huitong National Research Station of Forest Ecosystem $\left(26^{\circ} 40^{\prime}-27^{\circ} 09^{\prime} \mathrm{N}\right.$ 
and $109^{\circ} 26^{\prime}-110^{\circ} 08^{\prime}$ E) (Huitong Station, hereafter) in Hunan Province in the south of China. The Huitong Station is located at the transition zone from the YunnanGuizhou Plateau to the low mountains and hills on the southern side of the Yangtze River. This region has a typical mid-subtropical monsoon climate with an annual mean rainfall of $1200 \mathrm{~mm}$. The annual mean temperature is $16.5^{\circ} \mathrm{C}$ with a mean minimum of $1.9^{\circ} \mathrm{C}$ in January and a mean maximum of $29^{\circ} \mathrm{C}$ in July. The soil derived from the Sinian Period gray-green slate was classified as Ultisol according to the United States Department of Agriculture (USDA) soil taxonomy (He et al. 2016).

\section{Soil sampling}

The composition of soil aggregates and the response of SOC mineralization to $\mathrm{N}$ addition may differ across land use types. To investigate the role of soil aggregate composition on the effects of $\mathrm{N}$ addition on SOC mineralization, two land use types-a typical forest ecosystem and a paddy land-were selected for soil sampling because these two types are the main land use types in the subtropical region in China. Forest soils were from Chinese fir (Cunninghamia lanceolata (Lamb.) Hook) plantations that were established in 1983, 1989, and 1990 after clear-cutting and slash-burning practices of the natural evergreen broadleaf trees. In the Chinese fir plantation, the dominant species in the shrub layer were Maesa japonica, Mussaenda esquirolli, and Rhus chinensis, and those in the herbaceous layer were Miscanthus floridulu, Dicranopteris linearis, Herba lophatheri, Carex tristachya, and Parathelypteris glanduligera. At each site of Chinese fir plantations, a $20 \mathrm{~m} \times$ $20 \mathrm{~m}$ plot was selected. Crop rotation with Oryza sativa L. and Brassica campestris L. is typically applied for highly efficient utilization. O. sativa and $B$. campestris were planted in May and October in each year, respectively. Three sites of croplands were also selected. At each site, 10 soil cores at $0-10-\mathrm{cm}$ depths were randomly collected using a stainless steel cylinder with 5$\mathrm{cm}$ diameter and were composited into one soil sample. Soil samples from each land use type had three replicates. The forest soil samples were collected when the moisture content of the soil was $25-30 \%$ with cautious removal of floor residues. The paddy soil sampling was performed under the flooded condition because most of the growing season is under the flooded condition. A subsample (approximately $1 \mathrm{~kg}$ ) was immediately placed in a sterile plastic bag on ice when transported to the laboratory and stored at $4{ }^{\circ} \mathrm{C}$ for inoculum preparation. The remaining soils were passed through an $8-\mathrm{mm}$ sieve by gently breaking apart the soil, and air-dried in a laboratory for particle-size fractionation and subsequent $\mathrm{C}$ mineralization assays (Six et al. 2002). The plant residues including root and leaf litter, visible soil fauna, and stones were removed from the soil samples. The main properties of the forest and paddy soils in Huitong Station, subtropical China, are listed in Table 1.

\section{Soil particle-size separation}

The aggregate separation was conducted by wet sieving the soil through a series of three sieves (2000, 250, and $53 \mu \mathrm{m}$ ) to obtain three aggregate-size classes (Six et al. 2002). Prior to wet sieving, all field moist samples were passed through an 8-mm sieve and air-dried in a laboratory. The aggregates were separated using an aggregate sieving machine (AS200, Germany) by the following procedure. A subsample of $100 \mathrm{~g}$ of air-dried soil was submersed in deionized water in a beaker of $500 \mathrm{~mL}$ for 10 min to loosen the soil sample and then poured into the top of a $2000-\mu \mathrm{m}$ sieve. The aggregates were separated by moving the sieve up and down 50 times over a period of $2 \mathrm{~min}$ with an amplitude of $3 \mathrm{~cm}$. The intact aggregates that remained on the $2000-\mu \mathrm{m}$ sieve were scarce except the little rocks. The soil slurry that remained on the $250-\mu \mathrm{m}$ and $53-\mu \mathrm{m}$ sieves washed off the sieve and collected in an aluminum pan, considering as the macroaggregates and microaggregates, respectively. The $<53$ $\mu \mathrm{m}$ fraction was separated by centrifuging $(2500 \times g)$ the soil suspension that passed through the $53-\mu \mathrm{m}$ sieve and collected in an aluminum pan. All fractions in the aluminum pan were oven dried at $50^{\circ} \mathrm{C}$ and weighed to calculate the aggregate weight percentages. The procedure of aggregate separation was repeated until all fractions of the aggregates were sufficient for subsequent

Table 1 The main properties of forest and paddy soils in the Huitong National Research Station of Forest Ecosystem in Hunan Province, subtropical China

\begin{tabular}{|c|c|c|}
\hline Properties & Forest soil & Paddy soil \\
\hline $\mathrm{pH}$ & $3.43 \pm 0.04 a$ & $4.09 \pm 0.01 b$ \\
\hline $\mathrm{SOC}\left(\mathrm{mg} \mathrm{g}^{-1}\right)$ & $30.29 \pm 1.20 a$ & $24.12 \pm 1.11 b$ \\
\hline TN $\left(\mathrm{mg} \mathrm{g}^{-1}\right)$ & $2.15 \pm 0.13 a$ & $1.82 \pm 0.21 b$ \\
\hline $\mathrm{C} / \mathrm{N}$ & $14.10 \pm 0.92 a$ & $13.39 \pm 1.99 a$ \\
\hline $\mathrm{NH}_{4}^{+}-\mathrm{N}\left(\mathrm{mg} \mathrm{kg}^{-1}\right)$ & $24.09 \pm 1.11 a$ & $8.85 \pm 0.40 b$ \\
\hline $\mathrm{NO}_{3}-\mathrm{N}\left(\mathrm{mg} \mathrm{kg}^{-1}\right)$ & $2.24 \pm 0.17 a$ & $12.06 \pm 0.56 b$ \\
\hline $\mathrm{DOC}\left(\mathrm{mg} \mathrm{kg}^{-1}\right)$ & $39.09 \pm 5.06 a$ & $87.83 \pm 1.99 b$ \\
\hline $\operatorname{TP}\left(\mathrm{mg} \mathrm{g}^{-1}\right)$ & $0.45 \pm 0.06 a$ & $1.09 \pm 0.07 b$ \\
\hline $\mathrm{N} / \mathrm{P}$ & $4.84 \pm 0.66 a$ & $1.68 \pm 0.27 b$ \\
\hline TK $\left(\mathrm{mg} \mathrm{g}^{-1}\right)$ & $40.80 \pm 5.53 a$ & $41.32 \pm 5.46 a$ \\
\hline $\mathrm{MBC}\left(\mathrm{mg} \mathrm{kg}^{-1}\right)$ & $259.9 \pm 102.9 a$ & $1666.8 \pm 53.9 b$ \\
\hline $\mathrm{MBN}\left(\mathrm{mg} \mathrm{kg}^{-1}\right)$ & $63.06 \pm 12.94 a$ & $115.27 \pm 7.98 b$ \\
\hline $\mathrm{MBC} / \mathrm{MBN}$ & $4.02 \pm 0.74 a$ & $14.49 \pm 0.78 b$ \\
\hline Soil texture (\%, clay/silt/sand) & $45 / 49 / 6$ & $33 / 57 / 10$ \\
\hline
\end{tabular}

Different letters denote the significant differences between forest and paddy soils by Student's $T$-test $(p<0.05)$ 
incubation. All fractions were stored at room temperature for future use. Soil C and total N (TN) of all sizes of soil aggregates and bulk soils were determined using an automated $\mathrm{C} / \mathrm{N}$ analyzer (Vario MAX $\mathrm{CN}$, Elementar Co. Hanau, Germany). The soil total phosphorus (TP) was extracted by wet microwave digestion procedure and determined using an inductively coupled plasma mass spectrometry (ICP-MS, Thermo Scientific iCAP Q, USA).

\section{Laboratory incubation}

This incubation experiment included two land use types, three sizes of soil aggregates and their bulk soils, and four $\mathrm{N}$ addition treatments. Two land use types included forest and paddy land. The three sizes of soil aggregates were macroaggregates, microaggregates, and the $<53$ $\mu \mathrm{m}$ fraction. When the amount of $\mathrm{N}$ fertilizer applied to forest and paddy soils is $100 \mathrm{~kg} \mathrm{Nha}^{-1}$, and the average soil bulk density is approximately $1 \mathrm{~g} \mathrm{~cm}^{-3}$, then the concentration of $\mathrm{N}$ added into soils through $\mathrm{N}$ fertilizer application is equivalent to $100 \mu \mathrm{g} \mathrm{N} \mathrm{g}$ soil. Generally, the amount of $\mathrm{N}$ fertilizer applied to forest and paddy soils is $100 \mathrm{~kg} \mathrm{Nha}^{-1}$, and the $\mathrm{N}$ deposition is nearly 50 $\mathrm{kg} \mathrm{N} \mathrm{ha}^{-1}$ year $^{-1}$ in Hunan Province (Zhao et al. 2017). Thus, four $\mathrm{N}$ addition treatments were established as follows: N0 (without $\mathrm{N}$ addition), N1 $\left(50 \mu \mathrm{g} \mathrm{N} \mathrm{g}^{-1}\right), \mathrm{N} 2$ $\left(100 \mu \mathrm{g} \mathrm{N} \mathrm{g}{ }^{-1}\right)$, and N3 $\left(150 \mu \mathrm{g} \mathrm{N} \mathrm{g}^{-1}\right)$.

For each soil aggregate (macroaggregates, microaggregates, and the $<53-\mu \mathrm{m}$ fraction) and bulk soils, a $25-\mathrm{g}$ dried sample was placed into a $100-\mathrm{mL}$ brown jar and treated with $\mathrm{NH}_{4} \mathrm{NO}_{3}$. Because the microorganisms were interfered by oven-drying during soil aggregate separation, all sizes of soil aggregates were inoculated with the inocula from bulk soils to simulate the microbial community composition in bulk soils. Prior to $\mathrm{N}$ treatment, the inoculum solution was prepared by shaking $100 \mathrm{~g}$ of fresh bulk soil from subsample with $1000 \mathrm{~mL}$ of deionized water for $10 \mathrm{~min}$ and leaving to stand overnight to simulate the actual microbial community composition in forest and paddy soils (Christensen 1987). Five milliliters of inoculum dissolved 3.6, 7.2, and 10.7 mg of $\mathrm{NH}_{4} \mathrm{NO}_{3}$ was added to each sample to obtain the concentrations of added $\mathrm{N}$ equal to 50,100 , and $150 \mu \mathrm{g}$ $\mathrm{Ng}^{-1}$. The sample added with $5 \mathrm{~mL}$ of inoculum without $\mathrm{NH}_{4} \mathrm{NO}_{3}$ was the control. To improve soil aeration and uniformly disperse the inoculum, the sample added by the inoculum was loosened, stirred, and leveled slightly. The soil moisture was adjusted to $60 \%$ of field capacity. The soil aggregates were incubated at $20^{\circ} \mathrm{C}$ in an incubator for 90 days. This experiment had three replicates. Empty flasks were set as blank. The volume of head space (jar volume minus soil solid) was accurately measured after complementing the experiment by the method of water replacement. Since rewetting of dried sieved aggregates significantly increased $\mathrm{C}$ mineralization only during the early 3 days of the incubation experiment (Franzluebbers 1999), we preincubated the samples for 3 days to avoid the influence of disturbance (i.e., rewetting of dried soils and wet sieving) of field moist aggregates on soil $\mathrm{C}$ mineralization.

Soil respiration rates incubated at $20^{\circ} \mathrm{C}$ were determined using a Li-820 infrared gas analyzer (Li-Cor Inc. Lincoln, NE, USA). The measurements were conducted in $1,3,5,7,10,15,20,30,45,60$, and 90 days after incubation. The measurement for each sample lasted $6 \mathrm{~min}$ until a stable respiration rate is reached. After each measurement, each sample was returned to ambient $\mathrm{O}_{2}$ level by leaving the incubation jars open for $1 \mathrm{~h}$. The 100-mL incubation jars containing wetted soil aggregates (60\% of field capacity) were weighed prior to the incubation. The weight decrease of incubation jars due to water loss from the aggregates during each of the incubation period was compensated by the slow addition of deionized water using a water spray.

\section{Data analysis}

The cumulative $\mathrm{CO}_{2}-\mathrm{C}$ mineralization of different aggregate-size ranges (or bulk soils) during 90-day incubation was calculated as the cumulative mineralized $\mathrm{CO}_{2}-\mathrm{C}$ divided by the soil $\mathrm{C}$ content of the aggregates (or bulk soils). The effect size of $\mathrm{N}$ addition on $\mathrm{C}$ mineralization in aggregates and bulk soils was calculated by comparing the cumulative $\mathrm{CO}_{2}-\mathrm{C}$ mineralization after 90-day incubation with and without $\mathrm{N}$ addition treatments in different particle-size aggregates and bulk soils as follows:

$$
\text { Effect size }=\left(\mathrm{C}_{\text {min- } \mathrm{N}}-\mathrm{C}_{\text {min-withoutN }}\right) / \mathrm{C}_{\text {min-withoutN }} \text {, }
$$

where $\mathrm{C}_{\text {min-N }}\left(\mathrm{mg} \mathrm{CO}_{2}-\mathrm{C} \mathrm{g}^{-1}\right.$ soil $\left.\mathrm{C}\right)$ is the cumulative $\mathrm{CO}_{2}-\mathrm{C}$ mineralization in aggregates and bulk soils after 90-day incubation with $\mathrm{N}$ addition treatments and $\mathrm{C}_{\mathrm{min}--}$ withoutN ( $\mathrm{mg} \mathrm{CO} \mathrm{CO}_{2}-\mathrm{C} \mathrm{g}^{-1}$ soil $\mathrm{C}$ ) is the cumulative $\mathrm{CO}_{2}-\mathrm{C}$ mineralization in aggregates and bulk soils after 90-day incubation without $\mathrm{N}$ addition treatments (the control). The results show a positive effect when the effect size is $>0$ and a negative effect when the effect size is $<0$.

The cumulative $\mathrm{C}$ mineralization values and their effect sizes of $\mathrm{N}$ addition on soil aggregate $\mathrm{C}$ mineralization were analyzed using two-way ANOVA. Significant differences between the various treatments were tested with the Tukey HSD test. Statistical analysis was performed using SPSS 17.0 software (SPSS, Chicago, IL, USA). 


\section{Results}

\section{SOC, TN, and TP in different fractions}

The mass fractions of different particle sizes of aggregates in forest and paddy soils displayed the same trend. The largest proportion was found in the $<53-\mu \mathrm{m}$ fraction, followed by the microaggregates and the least in the macroaggregates (Table 2). No significance was found between the proportions of macroaggregates or microaggregates in forest and paddy soils, except that the $<53-\mu \mathrm{m}$ fraction in forest soil was lower than that in the paddy soil.

The SOC concentrations of aggregates in forest and paddy soils significantly increased with the increase in particle sizes $(p<0.05)$. The TN concentrations of different particle sizes of aggregates in forest soil did not vary, but the TN concentration of macroaggregates was $13.7 \%$ and $25.1 \%$ higher than that of the microaggregates and the $<53-\mu \mathrm{m}$ fraction in paddy soil, respectively $(p<$ $0.05)$. The TP concentrations did not vary among different particle sizes of aggregates in forest soil except that the TP concentration of macroaggregates was $28.7 \%$ and $21.6 \%$ higher than that of the microaggregates and the < $53-\mu \mathrm{m}$ fraction in paddy soil $(p<0.05)$. The TP concentrations of all sizes of aggregates in forest soil were much lower than those in paddy soil $(p<0.05)$. However, the $\mathrm{N}$ and $\mathrm{P}$ ratio (N:P ratio) of all sizes of aggregates in forest soil was significantly higher than those in paddy soil $(p<0.05)$.

\section{Differences in SOC mineralization rate among fractions}

The rates of $\mathrm{CO}_{2}-\mathrm{C}$ evolution of aggregates decreased with the incubation time. The rate of $\mathrm{CO}_{2}-\mathrm{C}$ evolution of macroaggregates was higher than that of microaggregates and the $<53-\mu \mathrm{m}$ fraction in forest and paddy soils (Fig. 1).

After 90-day incubation, the cumulative C mineralization ( $\mathrm{mg} \mathrm{CO}_{2}-\mathrm{C} \mathrm{g}^{-1}$ soil $\mathrm{C}$ ) in the $<53-\mu \mathrm{m}$ fraction, microaggregates, and macroaggregates was $40.4 \%, 15.2 \%$, and $16.0 \%$ higher than that of bulk soil in forest soil, respectively (Fig. $2 \mathrm{~A}, p<0.05$ ). The cumulative $\mathrm{C}$ mineralization did not differ significantly between the macroaggregates and microaggregates, but was significantly lower than that of the $<53-\mu \mathrm{m}$ fraction in forest soil $(p<0.05)$. The highest cumulative C mineralization was found in the $<53-\mu \mathrm{m}$ fraction in paddy soil, followed by bulk soil and macroaggregates. However, the cumulative $\mathrm{C}$ mineralization of microaggregates in paddy soil was the lowest (Fig. $2 \mathrm{~B}, p<0.05$ ).

\section{Effects of $\mathrm{N}$ addition on SOC mineralization rates}

The rates of $\mathrm{CO}_{2}-\mathrm{C}$ evolution of aggregates were decreased in forest soil but were increased in paddy soil (Fig. 1). Compared with that in the control treatment, the cumulative $\mathrm{C}$ mineralization of forest soil treated with N1, N2, and N3 significantly decreased by $20.0 \%$, $28.3 \%$, and $30.3 \%$ (Fig. 2A, $p<0.001$ ). There was an interaction effect between aggregate fractions and $\mathrm{N}$ addition on $\mathrm{C}$ mineralization of forest soil. Although $\mathrm{N}$ addition decreased the SOC mineralization of bulk soil and all sizes of aggregates, the reduction degree varied. The reduction of cumulative $\mathrm{C}$ mineralization of bulk soil was the least, and the reduction degree increased with decreasing particle size of aggregates in forest soil (Fig. 2A).

The cumulative $\mathrm{C}$ mineralization of paddy soil treated with N1, N2, and N3 significantly increased by $4.5 \%$, $13.0 \%$, and $2.8 \%$ compared with N0, respectively (Fig. 2B, $p<0.01)$. There was an interaction effect between aggregate fractions and $\mathrm{N}$ addition on $\mathrm{C}$ mineralization of paddy soil. The responses of SOC mineralization of different sizes of aggregates in paddy soil to $\mathrm{N}$ addition varied. Compared with N0, N1 significantly decreased the cumulative $\mathrm{C}$ mineralization of bulk soil, and N3 significantly decreased that of the macroaggregates, but $\mathrm{N} 2$ significantly increased that of the microaggregates and the $<53-\mu \mathrm{m}$ fraction (Fig. 1B, $p<0.05$ ).

The effect sizes of $\mathrm{N}$ addition on soil $\mathrm{C}$ mineralization of forest and paddy soils were quite different (Fig. 3). All effect sizes of forest soils treated with $\mathrm{N}$ addition were below zero, and the effect sizes decreased with the increasing $\mathrm{N}$ addition. However, most of effect sizes of

Table 2 C, total N (TN), and total P (TP) contents in the different sizes of aggregates in forest and paddy soils

\begin{tabular}{|c|c|c|c|c|c|c|c|}
\hline Soil & Particle size $(\mu \mathrm{m})$ & Proportion (\%) & $\mathrm{SOC}\left(\mathrm{mg} \mathrm{g}^{-1}\right)$ & $\mathrm{TN}\left(\mathrm{mg} \mathrm{g}^{-1}\right)$ & $\mathrm{C} / \mathrm{N}$ & $\mathrm{TP}\left(\mathrm{mg} \mathrm{g}^{-1}\right)$ & N/P \\
\hline \multirow[t]{4}{*}{ Forest soil } & Bulk soil & - & $30.3 \pm 1.2 c$ & $2.15 \pm 0.13 b$ & $14.1 \pm 0.9 \mathrm{~b}$ & $0.45 \pm 0.03 a$ & $4.83 \pm 0.51 b$ \\
\hline & $250-2000$ & $12.0 \pm 1.9 a$ & $43.3 \pm 1.6 \mathrm{e}$ & $2.07 \pm 0.05 b$ & $21.0 \pm 1.3 d$ & $0.43 \pm 0.04 a$ & $4.87 \pm 0.48 b$ \\
\hline & $53-250$ & $27.6 \pm 0.8 b$ & $28.3 \pm 1.8 c$ & $2.14 \pm 0.07 b$ & $13.2 \pm 0.7 b$ & $0.46 \pm 0.07 a$ & $4.72 \pm 0.94 b$ \\
\hline & $<53$ & $56.8 \pm 2.1 c$ & $19.3 \pm 1.7 a$ & $2.26 \pm 0.07 b$ & $8.5 \pm 0.5 a$ & $0.49 \pm 0.03 a$ & $4.64 \pm 0.35 b$ \\
\hline \multirow[t]{4}{*}{ Paddy soil } & Bulk soil & - & $24.1 \pm 1.1 b$ & $1.82 \pm 0.21 a$ & $13.4 \pm 2.0 b$ & $1.09 \pm 0.07 b$ & $1.68 \pm 0.27 a$ \\
\hline & $250-2000$ & $8.1 \pm 0.4 a$ & $34.9 \pm 2.4 \mathrm{~d}$ & $2.07 \pm 0.13 b$ & $16.9 \pm 0.4 c$ & $1.27 \pm 0.13 c$ & $1.65 \pm 0.27 a$ \\
\hline & $53-250$ & $25.2 \pm 5.8 b$ & $31.0 \pm 1.2 \mathrm{c}$ & $1.82 \pm 0.16 a$ & $17.1 \pm 0.9 c$ & $0.99 \pm 0.09 b$ & $1.85 \pm 0.25 a$ \\
\hline & $<53$ & $65.2 \pm 4.7 d$ & $21.6 \pm 1.2 \mathrm{ab}$ & $1.65 \pm 0.09 a$ & $13.1 \pm 0.2 b$ & $1.04 \pm 0.15 b$ & $1.60 \pm 0.17 a$ \\
\hline
\end{tabular}

Different letters denote the significant differences among different particle sizes of aggregates by one-way ANOVA $(p<0.05)$ 


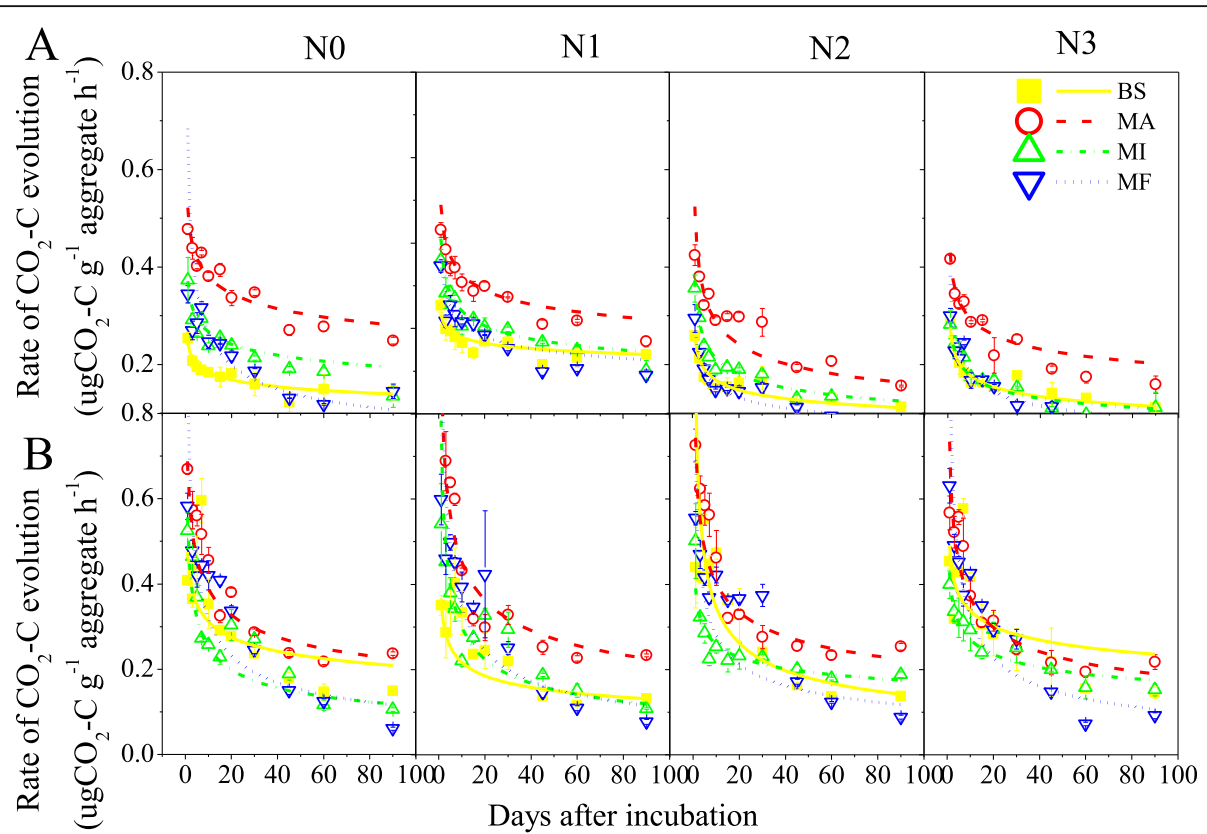

Fig. 1 Rate of $\mathrm{CO}_{2}-\mathrm{C}$ evolution from macroaggregates, microaggregate, and the $<53-\mu \mathrm{m}$ fraction during 3 months of incubation in a 100-mL incubation jar. $\mathbf{A}$ and $\mathbf{B}$ are the forest and paddy soils, respectively. The amount of $\mathrm{CO}_{2}-\mathrm{C}$ evolved from samples was determined using a Li-820 infrared gas analyzer. A non-linear asymptotic regression model was fitted to the $\mathrm{CO}_{2}-\mathrm{C}$ evolution rate of soil aggregates. BS, MA, Ml, and MF denote bulk soil, macroaggregate $(2000-250 \mu \mathrm{m})$, microaggregate $(250-53 \mu \mathrm{m})$, and the $<53-\mu \mathrm{m}$ fraction. N0 (the control), N1 $(50 \mu \mathrm{g} \mathrm{N} \mathrm{g}$ ), N2 $\left(100 \mu \mathrm{g} \mathrm{N}^{-1}\right)$, and N3 $\left(150 \mu \mathrm{g} \mathrm{N} \mathrm{g}^{-1}\right)$

paddy soils were above zero, in which the effect size of $\mathrm{N} 2$ was the highest.

\section{Discussion}

\section{Soil C mineralization differed among aggregates}

Soil aggregate size significantly affected SOC mineralization of forest and paddy soils. Our results showed that the cumulative $\mathrm{C}$ mineralization of microaggregates and the $<53-\mu \mathrm{m}$ fraction was higher than that of macroaggregates in forest soil, and it supported the hypothesis that the rates of $\mathrm{C}$ mineralization increase with decreasing class size of soil aggregates. This finding is consistent with the result reported by Xie et al. (2017). This pattern of SOC mineralization in aggregates in forest soil is due to the following causes. First, the physical protection of soil aggregates decreases SOC mineralization of macroaggregates. The formation of macroaggregates reduced the rate of soil aggregate turnover and protected the intra-aggregate particulate organic matter from microbial decomposition (Six et al. 2000; Blanco-Canqui and Lal 2004). During aggregate formation, organic particles were entrapped into macroaggregates and microaggregates, through the encrustation of SOM in the center of microaggregates, to prevent the accesses of microorganism (Golchin et al. 1994), resulting in the decreases of soil $C$ mineralization in macroaggregates. The protection of soil aggregates against soil $\mathrm{C}$ mineralization supported the result of the highest cumulative $C$ mineralization of the $<53-\mu \mathrm{m}$ fraction in forest soils in this study. Second, the soil C:N ratios of different particle sizes of aggregates in forest soils vary. The soil $\mathrm{C}: \mathrm{N}$ ratio can effectively predict soil $\mathrm{C}$ mineralization because it reflects the substrate quality for soil microorganism growth (Dai et al. 2017). SOM with higher $\mathrm{C}: \mathrm{N}$ ratio persists for longer times and has a lower rate of decomposition (Blanco-Canqui and Lal 2004). The C:N ratio of macroaggregates was higher compared with the microaggregates and the $<53-\mu \mathrm{m}$ fraction (Table 2), resulting in the lower rate of macroaggregate $\mathrm{C}$ mineralization in forest soils. Our results indicated again that soil aggregation plays an important role in forest soil $\mathrm{C}$ sequestration.

However, the cumulative $C$ mineralization of soil aggregates in paddy soils differed from that in forest soils. The lowest cumulative $\mathrm{C}$ mineralization appeared in microaggregates and that in the $<53-\mu \mathrm{m}$ fraction in paddy soils was the maximum probably due to the different biochemical properties of organic residues that bind mineral particles to form aggregates. The binding agents responsible for stabilizing the aggregates are classified as transient, temporary, and persistent agents (Tisdall and Oades 1982). The transient agents consist mainly of polysaccharides and organic mucilage, which can be rapidly decomposed by microbial processes 


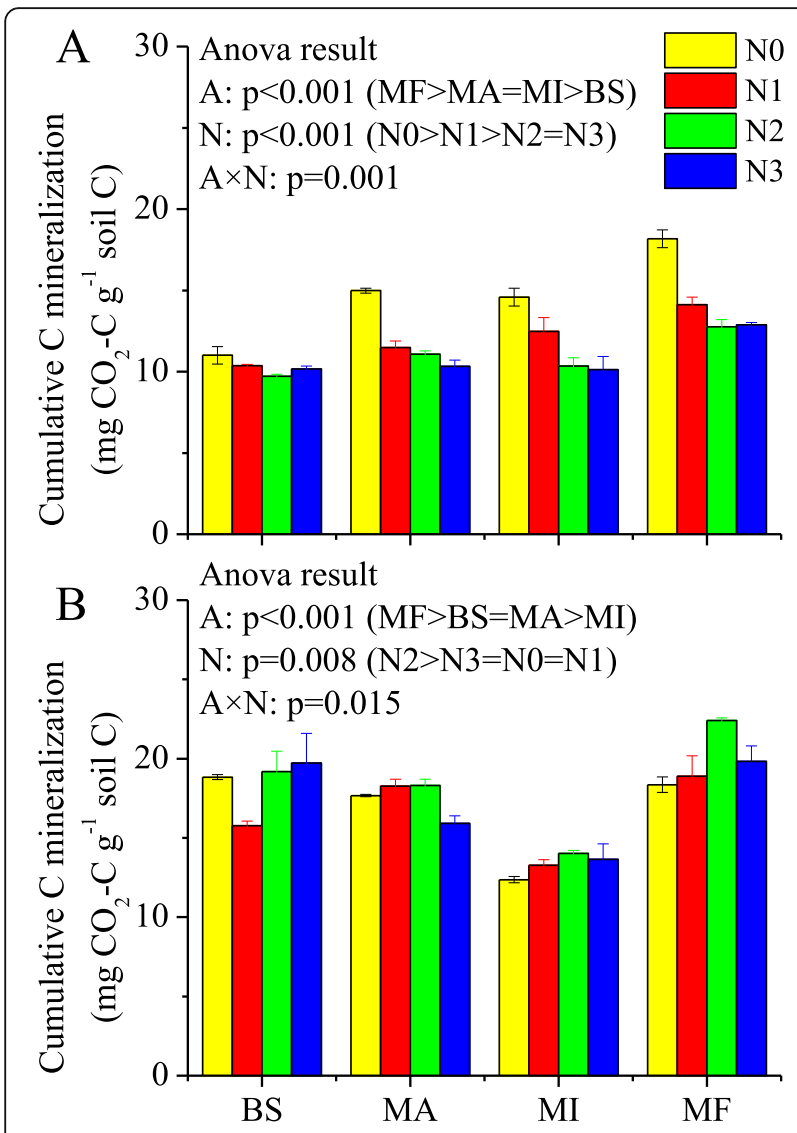

Fig. 2 The response of cumulative $C$ mineralization of aggregates to $\mathrm{N}$ addition in forest $(\mathbf{A})$ and paddy $(\mathbf{B})$ soils during the entire incubation period ( 90 days). BS, MA, MI, and MF denote bulk soil,

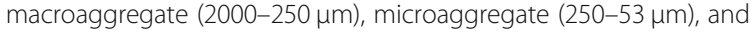
$<53-\mu \mathrm{m}$ fraction. NO (without N addition, the control), N1 $(50 \mu \mathrm{g} \mathrm{N}$ $\left.\mathrm{g}^{-1}\right), \mathrm{N} 2\left(100 \mathrm{\mu g} \mathrm{N} \mathrm{g}^{-1}\right)$, and N3 $\left(150 \mu \mathrm{g} \mathrm{N} \mathrm{g}^{-1}\right)$. F is the forest soils and $\mathrm{P}$ is the paddy soils. $\mathrm{A}$ and $\mathrm{N}$ denote the soil aggregates and $\mathrm{N}$ addition

(Blanco-Canqui and Lal 2004). They commonly bind 10$\mu \mathrm{m}$ to $50-\mu \mathrm{m}$ clay particles to form the $<53-\mu \mathrm{m}$ fraction (Martin 1971). Temporary agents comprising large substances, such as plant roots, fungal, and mycorhizal hyphae, bacterial cells, and algae, are mainly associated with soil macroaggregates (Tisdall and Oades 1982). Moreover, most of the macroaggregates were newly formed due to the annual periodic severe disturbance in paddy soils with the rotation of $O$. sativa and B. campestris. Persistent agents include highly decomposed organic materials, such as humic compounds, polymers, and polyvalent cations, and are associated with the formation of microaggregates (Edwards and Bremner 1967). Compared with temporary agents binding in macroaggregates, persistent agents in microaggregates have the lowest decomposition rates and the longest decomposition time, and the transient agents in the $<53-\mu \mathrm{m}$ fraction have the highest decomposition rates and the
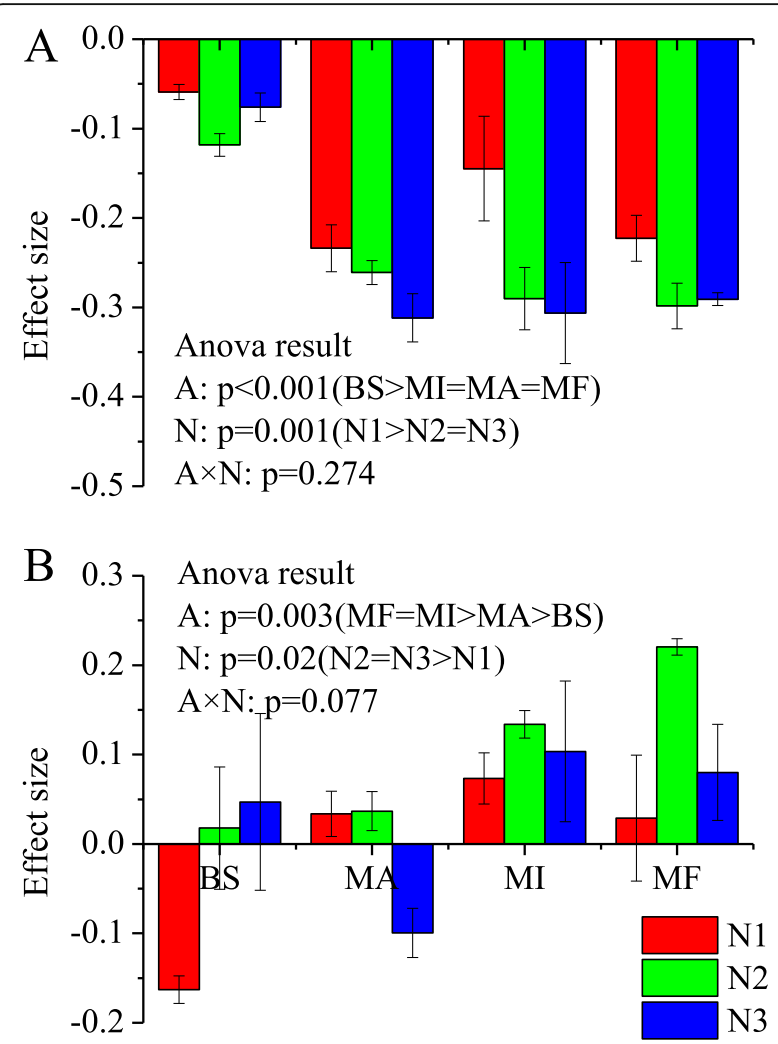

Fig. 3 The effect sizes of cumulative $\mathbf{C}$ mineralization of forest and paddy soils by $\mathbf{N}$ addition. $\mathbf{A}$ and $\mathbf{B}$ are the forest and paddy soils, respectively. $\mathrm{BS}, \mathrm{MA}, \mathrm{MI}$, and $\mathrm{MF}$ denote bulk soil, macroaggregate (2000-250 $\mu \mathrm{m})$, microaggregate $(250-53 \mu \mathrm{m})$, and < 53- $\mu \mathrm{m}$ fraction. $\mathrm{N} 1, \mathrm{~N} 2$, and $\mathrm{N} 3$ are $50 \mu \mathrm{g} \mathrm{N} \mathrm{g}^{-1}, 100 \mu \mathrm{g} \mathrm{Ng}^{-1}$, and $150 \mathrm{\mu g} \mathrm{N} \mathrm{g}^{-1}$, respectively

shortest decomposition time, resulting in the lowest and the highest cumulative $\mathrm{C}$ mineralization of microaggregates and the $<53-\mu \mathrm{m}$ fraction in paddy soils, respectively. Our results showed that microaggregates play a better role in $\mathrm{C}$ sequestration of paddy soil.

\section{Effects of $\mathrm{N}$ addition on $\mathrm{SOC}$ mineralization rates}

$\mathrm{N}$ addition exhibited diverse effects on the cumulative $\mathrm{C}$ mineralization and different effect sizes of soil aggregates in forest and paddy soils, which was consistent with our second hypothesis. Added $\mathrm{N}$ decreased cumulative $\mathrm{C}$ mineralization and effect sizes in all aggregates and bulk soils of the forest. This result confirmed the hypothesis that $\mathrm{N}$ addition reduced soil $\mathrm{C}$ mineralization of aggregates in forest soils. This result was in line with the findings in subtropical forest soil (Wang et al. 2017), tropical forest soil (Mo et al. 2008), and temperate forest soil (Janssens et al. 2010). Although there is a debate on the effects of $\mathrm{N}$ addition on SOC mineralization, most previous findings support the opinion that $\mathrm{N}$ addition impedes organic matter decomposition and thus stimulates 
carbon sequestration in forest soils (Franklin et al. 2003; Chen et al. 2012; Fisk et al. 2015; Wang et al. 2017).

However, the impacts of $\mathrm{N}$ addition on soil aggregate $\mathrm{C}$ mineralization in paddy soils differed from that in forest soils. $\mathrm{N}$ addition enhanced the cumulative $\mathrm{C}$ mineralization and effect sizes of soil aggregates in paddy soils, especially N2 treatment. This result indicated that the added $\mathrm{N}$ enhanced the amount of potential mineralizable $\mathrm{OC}$ of soil aggregates and promoted soil aggregate $\mathrm{C}$ mineralization in paddy soils. This finding was inconsistent with our hypothesis but was consistent with the previous documents that reported that $\mathrm{N}$ addition has promoting effects on $\mathrm{C}$ mineralization of paddy soils (Zheng et al. 2007; Li et al. 2014; Zhou et al. 2014). These results indicated that added $\mathrm{N}$ has diverse effects on soil C mineralization in forest and paddy soils.

Several possible mechanisms can explain the relationship between $\mathrm{N}$ addition and SOC mineralization. The first possible mechanism is that added $\mathrm{N}$ can negatively impact soil microbial biomass, composition, and activity (Treseder 2008). A number of documents reported that $\mathrm{N}$ addition reduces microbial biomass and activity, such as fungal biomass (Frey et al. 2004; Högberg et al. 2007), bacterial biomass (Blǎsko et al. 2013), and microbial abundance (Treseder 2008). A review on the effects of $\mathrm{N}$ addition on microbial biomass showed that the microbial biomass declined by $15 \%$ on average under $\mathrm{N}$ fertilization and suggested that the reduction of microbial biomass caused a corresponding decline in soil $\mathrm{CO}_{2}$ emissions under $\mathrm{N}$ addition (Treseder 2008). Soil microbial biomass and community composition control the rates and dynamics of SOC decomposition. Thus, the reduction in soil microbial biomass by $\mathrm{N}$ addition may result in the decline of SOC mineralization of aggregates. However, this hypothesis is suitable for forest soils, not for paddy soils. The second possible mechanism is that the added $\mathrm{N}$ reacts with the breakdown products of lignin degradation to form recalcitrant complexes, such as melanoidins (Fog 1988). However, the results of our study showed that the reductions of $\mathrm{C}$ mineralization of all aggregate sizes in forest soils have similar range under the same levels of added $\mathrm{N}$, despite the difference of $\mathrm{OC}$ concentrations in all aggregate sizes. Moreover, another document reported that only a small amount of added $\mathrm{N}$ is incorporated into the recalcitrant substrate (Clinton et al. 1995). Thus, this hypothesis is insufficient to support our findings. The third possible mechanism is "microbial N mining" theory (Moorhead and Sinsabaugh 2006). This theory assumes that the $\mathrm{N}$-acquiring microbes use labile $\mathrm{C}$ as an energy source to decompose recalcitrant organic matter to obtain $\mathrm{N}$. When $\mathrm{N}$ is added, the microorganism uses preferentially mineral $\mathrm{N}$ and has little incentive to break down the recalcitrant organic matter to acquire $\mathrm{N}$, resulting in the reductions of $\mathrm{C}$ mineralization of all aggregates with $\mathrm{N}$ addition. Therefore, our result is consistent with the prediction of "microbial $\mathrm{N}$ mining" theory. However, this theory does not work in paddy soil.

The above possible mechanisms can explain the effects of added $\mathrm{N}$ on $\mathrm{C}$ mineralization of soil aggregates in forest soil, but are unsuitable for paddy soil. Few possible mechanisms can explain the difference in soil C mineralization by $\mathrm{N}$ addition in forest and paddy soils. First, the special microbial communities in paddy soils were already adapted to high $\mathrm{N}$ availability (Hagedorn et al. 2012), contrary to the microbial communities in forest soils. To increase crop yield, a large amount of $\mathrm{N}$ fertilizer was applied in croplands, resulting in the change of microbial community compositions that adapted to high $\mathrm{N}$ availability in paddy soils. In our study, soil microbial biomass carbon (MBC) in paddy soils was $1667 \mathrm{mg} \mathrm{kg}^{-1}$ and was $541 \%$ higher than that in forest soils (260 $\mathrm{mg} \mathrm{kg}^{-1}$, Table 1$)$. When $\mathrm{N}$ is added into the paddy soils, the microbial communities adapting to high $\mathrm{N}$ availability may proliferate rapidly and then speed up the rate of SOC turnover. Therefore, the added $\mathrm{N}$ can enhance the microbial biomass and promote $\mathrm{C}$ mineralization of aggregates in paddy soil ( $\mathrm{Li}$ et al. 2014). Second, the responses of different soil carbon fractions to $\mathrm{N}$ addition varied. $\mathrm{N}$ addition significantly accelerates the decomposition of light fractions of soil organic carbon, but further decreases the C mineralization of heavy fractions through stabilization of soil C (Neff et al. 2002). The light fraction of soil organic matter is a labile OC characterized by rapid mineralization due to the labile nature of its chemical constituents, which have greater alkyl-to-O-alkyl ratio than the heavy fraction (Huang et al. 2011b). Labile OC is positively correlated to water-soluble SOC (Zhang et al. 2009). The water-soluble SOC of paddy soils $(87.8$ $\mathrm{mg} \mathrm{kg}^{-1}$ ) was much higher than that of forest soils (39.1 $\mathrm{mg} \mathrm{kg}^{-1}$ ), implying that more labile OC existed in paddy soils than that in forest soils. When $\mathrm{N}$ was added into paddy soils, the soil microorganisms preferred to use labile $\mathrm{OC}$ as energy and promoted soil microbial turnover, resulting in the accelerating effects of $\mathrm{N}$ addition on $\mathrm{C}$ mineralization of paddy soils.

\section{Conclusions}

The effects of $\mathrm{N}$ addition on soil $\mathrm{C}$ mineralization in aggregates in forest and paddy soils in subtropical China were investigated. Soil $\mathrm{C}$ mineralization decreased with the increasing sizes of soil aggregates in forest and paddy soils, implying that soil aggregates played an important role in the SOC stability and resulted in soil $\mathrm{C}$ sequestration. However, $\mathrm{N}$ addition exhibited diverse effects on soil $\mathrm{C}$ mineralization in forest and paddy soils in that it impeded soil $\mathrm{C}$ mineralization in forest soils but 
accelerated that in paddy soils. It indicated that land use type can affect the response of soil $\mathrm{C}$ mineralization to $\mathrm{N}$ addition. These results highlight the important role of soil aggregates and land use types in terrestrial ecosystem $\mathrm{C}$ cycle and sequestration under $\mathrm{N}$ enrichment. The heterogeneity of soil aggregates and the patch pattern of land use types in global landscape scales increase the uncertainty of soil $C$ sequestration of terrestrial ecosystems with $\mathrm{N}$ deposition. Due to the role of soil aggregates and land use types in soil $\mathrm{C}$ sequestration, future soil $\mathrm{C}$ management should be focused on soil aggregates and land use types to alleviate global climate change.

\section{Abbreviations}

C: Carbon; SOC: Soil organic carbon; N: Nitrogen; USDA: United States Department of Agriculture; TN: Total nitrogen; TP: Total phosphorus

\section{Acknowledgements}

Thanks to two anonymous reviewers for their good comments. This study was supported by the National Natural Science Foundation of China (41630755 and 31971718).

\section{Authors' contributions}

LC has designed this experiment and written the manuscript. RC has conducted this experiment and analyzed the data. $\mathrm{XH}, \mathrm{XL}$, and $\mathrm{HL}$ reviewed the manuscript. All authors have read and agreed to the published version of the manuscript.

\section{Funding}

The National Natural Science Foundation of China (41630755 and 31971718).

\section{Availability of data and materials}

The datasets used and/or analyzed during the current study are available from the corresponding author on reasonable request.

\section{Declarations}

\section{Ethics approval and consent to participate}

Not applicable

\section{Consent for publication}

All authors agreed and approved the manuscript for publication in Ecological Processes.

\section{Competing interests}

The authors declare that they have no competing interests.

\begin{abstract}
Author details
${ }^{1}$ College of Landscape Architecture and Forestry, Qingdao Agricultural University, Qingdao 266109, China. ${ }^{2}$ Huitong Experimental Station of Forest Ecology, CAS Key Laboratory of Forest Ecology and Management, Institute of Applied Ecology, Chinese Academy of Sciences, Shenyang 110016, China. ${ }^{3}$ Hunan Key Laboratory for Structure and Ecosystem Service of Subtropical Forest, Huitong National Research Station of Forest Ecosystem, Huitong 418307, China. ${ }^{4}$ Research and Development Center for Grasses and Environment, Beijing Academy of Agriculture and Forestry Sciences, Beijing 100097, China
\end{abstract}

Received: 8 April 2021 Accepted: 7 June 2021

Published online: 23 June 2021

\section{References}

Aber J, McDowell W, Nadelhoffer K, Magill A, Berntson G, Kamakea M, McNulty S, Currie W, Rustad L, Fernandez I (1998) Nitrogen saturation in temperate forest ecosystems - hypotheses revisited. Bioscience 48(11):921-934. https:// doi.org/10.2307/1313296
Allison SD, Czimczik Cl, Treseder KK (2008) Microbial activity and soil respiration under nitrogen addition in Alaskan boreal forest. Glob Chang Biol 14(5): 1156-1168. https://doi.org/10.1111/j.1365-2486.2008.01549.x

Allison SD, LeBauer DS, Ofrecio MR, Reyes R, Ta AM, Tran TM (2009) Low levels of nitrogen addition stimulate decomposition by boreal forest fungi. Soil Biol Biochem 41(2):293-302. https://doi.org/10.1016/j.soilbio.2008.10.032

Bellamy PH, Loveland PJ, Bradley RL, Lark RM, Kirk GJD (2005) Carbon losses from all soils across England and Wales 1978-2003. Nature 437(7056):245-248. https://doi.org/10.1038/nature04038

Besnard E, Chenu C, Balesdent J, Puget P, Arrouays D (1996) Fate of particulate organic matter in soil aggregates during cultivation. Eur J Soil Sci 47(4):495503. https://doi.org/10.1111/j.1365-2389.1996.tb01849.x

Bimüller C, Kreyling O, Kölbl A, von Lützow M, Kögel-Knabner I (2016) Carbon and nitrogen mineralization in hierarchically structured aggregates of different size. Soil Tillage Res 160:23-33. https://doi.org/10.1016/j.still.2015.12. 011

Blanco-Canqui H, Lal R (2004) Mechanisms of carbon sequestration in soil aggregates. Crit Rev Plant Sci 23(6):481-504. https://doi.org/10.1080/07352 680490886842

Blăsko R, Högberg P, Bach LH, Hogberg MN (2013) Relations among soil microbial community composition, nitrogen turnover, and tree growth in Nloaded and previously N-loaded boreal spruce forest. For Ecol Manag 302: 319-328. https://doi.org/10.1016/j.foreco.2013.02.035

Chaplot V, Cooper M (2015) Soil aggregate stability to predict organic carbon outputs from soils. Geoderma 243:205-213

Chen XM, Liu JX, Deng Q, Yan JH, Zhang DQ (2012) Effects of elevated $\mathrm{CO}_{2}$ and nitrogen addition on soil organic carbon fractions in a subtropical forest. Plant Soil 357(1-2):25-34. https://doi.org/10.1007/s11104-012-1145-3

Christensen BT (1987) Decomposability of organic-matter in particle-size fractions from field soils with straw incorporation. Soil Biol Biochem 19(4):429-435. https://doi.org/10.1016/0038-0717(87)90034-4

Cleveland CC, Townsend AR (2006) Nutrient additions to a tropical rain forest drive substantial soil carbon dioxide losses to the atmosphere. PNAS 103(27): 10316-10321. https://doi.org/10.1073/pnas.0600989103

Clinton PW, Newman RH, Allen RB (1995) Immobilization of ${ }^{15} \mathrm{~N}$ in forest litter studied by ${ }^{15} \mathrm{~N}$ CPMAS NMR spectroscopy. Eur J Soil Sci 46(4):551-556. https://doi.org/10.1111/j.1365-2389.1995.tb01351.x

Contosta AR, Frey SD, Ollinger SV, Cooper AB (2013) Soil respiration does not acclimatize to warmer temperatures when modeled over seasonal timescales. Biogeochemistry 112(1-3):555-570. https://doi.org/10.1007/s1 0533-012-9748-6

Dai XQ, Wang HM, Fu XL (2017) Soil microbial community composition and its role in carbon mineralization in long-term fertilization paddy soils. Sci Total Environ 580:556-563. https://doi.org/10.1016/j.scitotenv.2016.11.212

Drury CF, Yang XM, Reynolds WD, Tan CS (2004) Influence of crop rotation and aggregate size on carbon dioxide production and denitritication. Soil Tillage Res 79(1):87-100. https://doi.org/10.1016/j.still.2004.03.020

Edwards AP, Bremner JM (1967) Microaggregates in soils. J Soil Sci 18:65-73

Fisk M, Santangelo S, Minick K (2015) Carbon mineralization is promoted by phosphorus and reduced by nitrogen addition in the organic horizon of northern hardwood forests. Soil Biol Biochem 81:212-218. https://doi.org/1 0.1016/j.soilbio.2014.11.022

Fog K (1988) The effect of added nitrogen on the rate of decomposition of organic matter. Biol Rev 63(3):433-462. https://doi.org/10.1111/j.1469-185X.1 988.tb00725.x

Franklin O, Högberg P, Ekblad A, Ågren Gl (2003) Pine forest floor carbon accumulation in response to $\mathrm{N}$ and PK additions: bomb ${ }^{14} \mathrm{C}$ modelling and respiration studies. Ecosystems 6(7):644-658. https://doi.org/10.1007/s10021002-0149-x

Franzluebbers AJ (1999) Potential C and N mineralization and microbial biomass from intact and increasingly disturbed soils of varying texture. Soil Biol Biochem 31(8):1083-1090. https://doi.org/10.1016/S0038-0717(99)00022-X

Frey SD, Knorr M, Parrent JL, Simpson RT (2004) Chronic nitrogen enrichment affects the structure and function of the soil microbial community in temperate hardwood and pine forests. For Ecol Manag 196(1):159-171. https://doi.org/10.1016/j.foreco.2004.03.018

Galloway JN, Townsend AR, Erisman JW, Bekunda M, Cai ZC, Freney JR, Martinelli LA, Seitzinger SP, Sutton MA (2008) Transformation of the nitrogen cycle: recent trends, questions, and potential solutions. Science 320(5878):889-892. https://doi.org/10.1126/science.1136674 
Goebel MO, Bachmann J, Woche SK, Fischer WR (2005) Soil wettability, aggregate stability, and the decomposition of soil organic matter. Geoderma 128(1-2): 80-93. https://doi.org/10.1016/j.geoderma.2004.12.016

Golchin A, Oades JM, Skjemstad JO, Clarke P (1994) Soil-structure and carbon cycling. Aust J Soil Res 32(5):1043-1068. https://doi.org/10.1071/SR9941043

González-Rosado M, Parras-Alcántara L, Aguilera-Huertas J, Benítez C, LozanoGarcía B (2020) Effects of land management change on soil aggregates and organic carbon in Mediterranean olive groves. Catena 195:104840. https:// doi.org/10.1016/j.catena.2020.104840

Guo H, Ye CL, Zhang H, Pan S, Ji YG, Li Z, Liu MQ, Zhou X, Du GZ, Hu F, Hu SJ (2017) Long-term nitrogen \& phosphorus additions reduce soil microbial respiration but increase its temperature sensitivity in a Tibetan alpine meadow. Soil Biol Biochem 113:26-34. https://doi.org/10.1016/j.soilbio.2017. 05.024

Hagedorn F, Kammer A, Schmidt MWI, Goodale CL (2012) Nitrogen addition alters mineralization dynamics of ${ }^{13} \mathrm{C}$-depleted leaf and twig litter and reduces leaching of older DOC from mineral soil. Glob Chang Biol 18(4): 1412-1427. https://doi.org/10.1111/j.1365-2486.2011.02603.x

He T, Wang Q, Wang S, Zhang F (2016) Nitrogen addition altered the effect of belowground $\mathrm{C}$ allocation on soil respiration in a subtropical forest. PLoS One 11(5):e0155881. https://doi.org/10.1371/journal.pone.0155881

Högberg MN, Högberg P, Myrold DD (2007) Is microbial community composition in boreal forest soils determined by $\mathrm{pH}, \mathrm{C}$-to- $\mathrm{N}$ ratio, the trees, or all three? Oecologia 150(4):590-601. https://doi.org/10.1007/s00442-006-0562-5

Hu YW, Zhang L, Deng BL, Liu YQ, Liu Q, Zheng X, Zheng LY, Kong FQ, Guo XM, Siemann $E$ (2017) The non-additive effects of temperature and nitrogen deposition on $\mathrm{CO}_{2}$ emissions, nitrification, and nitrogen mineralization in soils mixed with termite nests. Catena 154:12-20. https://doi.org/10.1016/j.ca tena.2017.02.014

Huang ZQ, Clinton PW, Baisden WT, Davis MR (2011a) Long-term nitrogen additions increased surface soil carbon concentration in a forest plantation despite elevated decomposition. Soil Biol Biochem 43(2):302-307. https://doi. org/10.1016/j.soilbio.2010.10.015

Huang ZQ, Clinton PW, Davis MR, Yang YS (2011b) Impacts of plantation forest management on soil organic matter quality. J Soils Sediments 11(8):13091316. https://doi.org/10.1007/s11368-011-0440-6

Janssens IA, Dieleman W, Luyssaert S, Subke JA, Reichstein M, Ceulemans R, Ciais P, Dolman AJ, Grace J, Matteucci G, Papale D, Piao SL, Schulze ED, Tang J, Law BE (2010) Reduction of forest soil respiration in response to nitrogen deposition. Nat Geosci 3(5):315-322. https://doi.org/10.1038/ngeo844

Kirkby CA, Richardson AE, Wade LJ, BattenB GD, Blanchard C, Kirkegaard JA (2013) Carbon-nutrient stoichiometry to increase soil carbon sequestration. Soil Biol Biochem 60:77-86. https://doi.org/10.1016/j.soilbio.2013.01.011

Lal R (2004) Soil carbon sequestration impacts on global climate change and food security. Science 304(5677):1623-1627. https://doi.org/10.1126/science.1 097396

Li YK, Chen MP, Mei XR, Xia X, Guo WZ, Li HR, Hao WP (2014) Effects of soil moisture and nitrogen addition on organic carbon mineralization in a highyield cropland soil of the North China plain. Acta Ecol Sin 34:4037-4046

Liu Y, Wang CH, He NP, Wen XF, Gao Y, Li SG, Niu SL, Butterbach-Bahl K, Luo YQ, Yu GR (2017) A global synthesis of the rate and temperature sensitivity of soil nitrogen mineralization: latitudinal patterns and mechanisms. Glob Chang Biol 23(1):455-464. https://doi.org/10.1111/gcb.13372

Martin JP (1971) Decomposition and binding action of polysaccharides in soil. Soil Biol Biochem 3(1):33-41. https://doi.org/10.1016/0038-0717(71)90029-0

Micks P, Aber JD, Boone RD, Davidson EA (2004) Short-term soil respiration and nitrogen immobilization response to nitrogen applications in control and nitrogen-enriched temperate forests. For Ecol Manag 196(1):57-70. https:// doi.org/10.1016/j.foreco.2004.03.012

Mo J, Zhang W, Zhu W, Gundersen P, Fang Y, Li D, Wang H (2008) Nitrogen addition reduces soil respiration in a mature tropical forest in southern China. Glob Chang Biol 14(2):403-412. https://doi.org/10.1111/j.1365-2486.2 007.01503.x

Moorhead DL, Sinsabaugh RL (2006) A theoretical model of litter decay and microbial interaction. Ecol Monogr 76(2):151-174. https://doi.org/10.1890/ 0012-9615(2006)076[0151:ATMOLD]2.0.CO;2

Neff JC, Townsend AR, Gleixner G, Lehman SJ, Turnbull J, Bowman WD (2002) Variable effects of nitrogen additions on the stability and turnover of soil carbon. Nature 419(6910):915-917. https://doi.org/10.1038/nature01136

Okolo CC, Gebresamuel G, Zenebe A, Haile M, Eze PN (2020) Accumulation of organic carbon in various soil aggregate sizes under different land use systems in a semi-arid environment. Agric Ecosyst Environ 297:106924. https://doi.org/10.1016/j.agee.2020.106924

Poeplau C, Herrmann AM, Kätterer T (2016) Opposing effects of nitrogen and phosphorus on soil microbial metabolism and the implications for soil carbon storage. Soil Biol Biochem 100:83-91. https://doi.org/10.1016/j. soilbio.2016.05.021

Qiu HS, Ge TD, Liu JY, Chen XB, Hu YJ, Wu JS, Su YR, Kuzyakov Y (2018) Effects of biotic and abiotic factors on soil organic matter mineralization: experiments and structural modeling analysis. Eur J Soil Biol 84:27-34. https://doi.org/10.1 016/j.ejsobi.2017.12.003

Razafimbelo TM, Albrecht A, Oliver R, Chevallier T, Chapuis-Lardy L, Feller C (2008) Aggregate associated-C and physical protection in a tropical clayey soil under Malagasy conventional and no-tillage systems. Soil Tillage Res 98(2): 140-149. https://doi.org/10.1016/j.still.2007.10.012

Reed SC, Vitousek PM, Cleveland CC (2010) Are patterns in nutrient limitation belowground consistent with those aboveground: results from a 4 million year chronosequence. Biogeochemistry 106:323-336

Reeves SH, Somasundaram J, Wang WJ, Heenan MA, Finn D, Dalai RC (2019) Effect of soil aggregate size and long-term contrasting tillage, stubble and nitrogen management regimes on $\mathrm{CO}_{2}$ fluxes from a vertisol. Geoderma 337: 1086-1096. https://doi.org/10.1016/j.geoderma.2018.11.022

Riggs CE, Hobbie SE, Bach EM, Hofmockel KS, Kazanski CE (2015) Nitrogen addition changes grassland soil organic matter decomposition. Biogeochemistry 125(2):203-219. https://doi.org/10.1007/s10533-015-0123-2

Schlesinger WH, Andrews JA (2000) Soil respiration and the global carbon cycle. Biogeochemistry 48(1):7-20. https://doi.org/10.1023/A:1006247623877

Sithole NJ, Magwaza LS, Thibaud GR (2019) Long-term impact of no-till conservation agriculture and $\mathrm{N}$-fertilizer on soil aggregate stability, infiltration and distribution of $C$ in different size fractions. Soil Tillage Res 190:147-156. https://doi.org/10.1016/j.still.2019.03.004

Six J, Callewaert P, Lenders S, De Gryze S, Morris SJ, Gregorich EG, Paul EA, Paustian K (2002) Measuring and understanding carbon storage in afforested soils by physical fractionation. Soil Sci Soc Am J 66(6):1981-1987. https://doi. org/10.2136/sssaj2002.1981

Six J, Elliott ET, Paustian K, Doran JW (1998) Aggregation and soil organic matter accumulation in cultivated and native grassland soils. Soil Sci Soc Am J 62(5): 1367-1377. https://doi.org/10.2136/sssaj1998.03615995006200050032x

Six J, Paustian K (2014) Aggregate-associated soil organic matter as an ecosystem property and a measurement tool. Soil Biol Biochem 68:A4-A9. https://doi. org/10.1016/j.soilbio.2013.06.014

Six J, Paustian K, Elliott ET, Combrink C (2000) Soil structure and soil organic matter: I. Distribution of aggregate size classes and aggregate associated carbon. Soil Sci Soc Am J 64:681-689

Soong JL, Maranon-Jimenez S, Cotrufo MF, Boeckx P, Bode S, Guenet B, Penuelas J, Richter A, Stahl C, Verbruggen E, Janssens IA (2018) Soil microbial CNP and respiration responses to organic matter and nutrient additions: evidence from a tropical soil incubation. Soil Biol Biochem 122:141-149. https://doi. org/10.1016/j.soilbio.2018.04.011

Tian QX, He HB, Cheng WX, Bai Z, Wang Y, Zhang XD (2016) Factors controlling soil organic carbon stability along a temperate forest altitudinal gradient. Sci Rep 6:18783

Tisdall JM, Oades JM (1982) Organic matter and water-stable aggregates in soils. Eur J Soil Sci 33(2):141-163. https://doi.org/10.1111/j.1365-2389.1982.tb01755.x

Treseder KK (2008) Nitrogen additions and microbial biomass: a meta-analysis of ecosystem studies. Ecol Lett 11(10):1111-1120. https://doi.org/10.1111/j.14610248.2008.01230.x

von Lützow M, Kögel-Knabner I, Ludwig B, Matzner E, Flessa H, Ekschmitt K, Guggenberger G, Marschner B, Kalbitz K (2008) Stabilization mechanisms of organic matter in four temperate soils: development and application of a conceptual model. J Plant Nutr Soil Sci 171(1):111-124. https://doi.org/10.1 002/jpln.200700047

Wang Q, Wang D, Wen X, Yu G, He N, Wang R (2015) Differences in SOM decomposition and temperature sensitivity among soil aggregate size classes in a temperate grasslands. PLoS One 10(2):e0117033. https://doi.org/10.1371/ journal.pone.0117033

Wang Q, Zhang W, Sun T, Chen L, Pang X, Wang Y, Xiao F (2017) N and P fertilization reduced soil autotrophic and heterotrophic respiration in a young Cunninghamia lanceolata forest. Agric For Meteorol 232:66-73. https://doi.org/10.1016/j.agrformet.2016.08.007 
Wang QK, Zeng ZQ, Zhong MC (2016) Soil moisture alters the response of soil organic carbon mineralization to litter addition. Ecosystems 19(3):450-460. https://doi.org/10.1007/s10021-015-9941-2

Wiesmeier M, Urbanski L, Hobley E, Lang B, von Lützow M, Marin-Spiotta E, van Wesemael B, Rabot E, Ließ M, Garcia-Franco N, Wollschläger U, Vogel H-J, Kögel-Knabner I (2019) Soil organic carbon storage as a key function of soils - a review of drivers and indicators at various scales. Geoderma 333:149-162. https://doi.org/10.1016/j.geoderma.2018.07.026

Xie JY, Hou MM, Zhou YT, Wang RJ, Zhang SL, Yang XY, Sun BH (2017) Carbon sequestration and mineralization of aggregate-associated carbon in an intensively cultivated Anthrosol in North China as affected by long term fertilization. Geoderma 296:1-9. https://doi.org/10.1016/j.geoderma.2017.02. 023

Yang C, Liu N, Zhang YJ (2017) Effects of aggregates size and glucose addition on soil organic carbon mineralization and $\mathrm{Q}_{10}$ values under wide temperature change conditions. Eur J Soil Biol 80:77-84. https://doi.org/10.1 016/j.ejsobi.2017.04.002

Yanni SF, Diochon A, Helgason BL, Ellert BH, Gregorich EG (2018) Temperature response of plant residue and soil organic matter decomposition in soil from different depths. Eur J Soil Sci 69(2):325-335. https://doi.org/10.1111/ejss.12 508

Zhang J, Wang SL, Feng ZW, Wang QK (2009) Carbon mineralization of soils from native evergreen broadleaf forest and three plantations in mid-subtropic China. Commun Soil Sci Plant Anal 40(11-12):1964-1982. https://doi.org/10.1 080/00103620902896795

Zhao YH, Zhang L, Chen YF, Liu XJ, Xu W, Pan YP, Duan L (2017) Atmospheric nitrogen deposition to China: a model analysis on nitrogen budget and critical load exceedance. Atmos Environ 153:32-40. https://doi.org/10.1016/j.a tmosenv.2017.01.018

Zhao Z, Wei X, Wang X, Ma T, Huang L, Gao H, Fan J, Li X, Jia X (2019) Concentration and mineralization of organic carbon in forest soils along a climatic gradient. For Ecol Manag 432:246-255. https://doi.org/10.1016/j. foreco.2018.09.026

Zheng J, Zhang X, Li L, Zhang P, Pan G (2007) Effect of long-term fertilization on $\mathrm{C}$ mineralization and production of $\mathrm{CH}_{4}$ and $\mathrm{CO}_{2}$ under anaerobic incubation from bulk samples and particle size fractions of a typical paddy soil. Agric Ecosyst Environ 120(2-4):129-138. https://doi.org/10.1016/j.agee.2006.07.008

Zhong ZK, Han XH, Xu YD, Zhang W, Fu SY, Liu WC, Ren CJ, Yang GH, Ren GX (2019) Effects of land use change on organic carbon dynamics associated with soil aggregate fractions on the loess plateau, China. Land Degrad Dev 30(9):1070-1082. https://doi.org/10.1002/ldr.3294

Zhou L, Zhou X, Zhang B, Lu M, Luo Y, Liu L, Li B (2014) Different responses of soil respiration and its components to nitrogen addition among biomes: a meta-analysis. Glob Chang Biol 20(7):2332-2343. https://doi.org/10.1111/ gcb. 12490

Zhu C, Ma YP, Wu HH, Sun T, La Pierre KJ, Sun ZW, Yu Q (2016) Divergent effects of nitrogen addition on soil respiration in a semiarid grassland. Sci Rep 6(1): 33541. https://doi.org/10.1038/srep33541

Zhu ZK, Ge TD, Liu SL, Hu YJ, Ye RZ, Xiao ML, Tong CL, Kuzyakov Y, Wu JS (2018a) Rice rhizodeposits affect organic matter priming in paddy soil: the role of $\mathrm{N}$ fertilization and plant growth for enzyme activities, $\mathrm{CO}_{2}$ and $\mathrm{CH}_{4}$ emissions. Soil Biol Biochem 116:369-377. https://doi.org/10.1016/j.soilbio.201 7.11 .001

Zhu ZK, Ge TD, Luo Y, Liu SL, Xu XL, Tong CL, Shibistova O, Guggenberger G, Wu JS (2018b) Microbial stoichiometric flexibility regulates rice straw mineralization and its priming effect in paddy soil. Soil Biol Biochem 121:6776. https://doi.org/10.1016/j.soilbio.2018.03.003

\section{Publisher's Note}

Springer Nature remains neutral with regard to jurisdictional claims in published maps and institutional affiliations.

\section{Submit your manuscript to a SpringerOpen ${ }^{\circ}$ journal and benefit from:}

- Convenient online submission

- Rigorous peer review

- Open access: articles freely available online

- High visibility within the field

- Retaining the copyright to your article

Submit your next manuscript at $\boldsymbol{\nabla}$ springeropen.com 